\title{
HISTORY
}

Copyright $(\odot 2018$ by the Kalmyk Scientific Center of the Russian Academy of Sciences

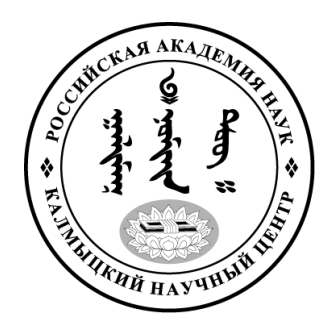

Published in the Russian Federation

Oriental Studies (Previous Name: Bulletin of the Kalmyk Institute for Humanities of the Russian Academy of Sciences)

Has been issued as a journal since 2008

ISSN: 2619-0990; E-ISSN: 2619-1008

Vol. 39, Is. 5, pp. 2-13, 2018

DOI 10.22162/2619-0990-2018-39-5-2-13

Journal homepage: https://kigiran.elpub.ru

УДК 9 (93/94)

\section{Усиление российского политического влияния и административная реформа в Туве}

Аяна Анай-ооловна Самдан

${ }^{1}$ кандидат исторических наук, ведущий научный сотрудник, Тувинский институт гуманитарных и прикладных социально-экономических исследований (667000, Россия, Республика Тыва, г. Кызыл, ул. Кочетова, д. 4). ORCID: 0000-0002-7785-7497. E-mail: camayana@mail.ru

\section{Аннотация}

Введение. В статье освещается процесс включения тувинцев в российское политическое пространство путем установления протектората России над Урянхайским краем. Царская власть разрабатывала различные планы по распространению своего влияния, в том числе и военный захват края. Эти проблемы обсуждались на разных уровнях российских властей. Одним из самых дискуссионных вопросов стала задача администрирования как местного, так и русского населения. Результатом совещаний стала выработка умеренной политики - постепенного укрепления своего влияния в крае путем переселения русских крестьян в Туву.

Цель. Изучить вопросы административно-территориального управления в Туве после установления российского протектората в 1914 г.

Meтоды и материаль. При написании статьи были использованы эмпирические методы сравнения, описания, интерпретации, системного анализа; теоретические методы историзма, формальной и диалектической логики. Материалом послужили ахивные документы Государственного архива Республики Тыва, а также Научного архива Тувинского интитута гуманитарно-прикладных исследований, которые впервые вводятся в оборот.

Результаты. Архивные документы свидетельствуют, что политическая ситуация требовала коррекции системы управления в крае, в частности, организации российских органов власти, их компетенции, порядка взаимодействия комиссариата и переселенческого управления, взаимоотношения этих органов с местным, а также с русским и тувинским населением. Представителями русских властей назначались опытные, инициативные чиновники (А. П. Церерин, В. К. Габаев, В. Ю. Григорьев), и во многом благодаря их усилиям, энергичным действиям стали возможны принятие протектората и дальнейшие административно-территориальные реформы в крае. Порой текущие важные вопросы (строительство Усинского тракта, конфликты между местным и пришлым населением) требовали вмешательства Иркутского генерал-губернатора.

Bblвoдbl. Автор считает, что на волне Синьхайской революции в Китае усилились позиции России в Туве. Русские чиновники избрали путь косвенного управления, устанавливая тесные контакты с правителями хошунов или же ставя правителями лояльных к ним людей. Такой подход способствовал формированию новых политических элит в Туве. Благодаря этим 
усилиям удалось отстранить от власти монголов, и всеми тувинскими хошунами и сумонами стали править тувинцы. Так, правителем одного из многочисленных хошунов был избран лама К. Чымба, а из четырех сумонов образовали 2 новых хошуна.

Тувинская политическая элита не смогла выработать единого мнения в вопросе самоопределения страны. Это можно объяснить их некоторым индифферентным отношением к будущей судьбе страны и опять же тяготением к старым порядкам управления.

Ключевые слова: Урянхайский край, русские власти, Комбу-Доржу, протекторат, совещания, иркутский генерал-губернатор, административная реформа, Синьхайская революция

\section{Введение}

С самого начала XX в. в разных провинциях Китая вспыхивали народные восстания. По всему Китаю распространялись антицинские настроения. В 1910 г. российский посланник в Пекине И. Я. Коростовец писал: «В сущности все население Китая охвачено духом протеста против существующего строя и готово при первом удобном случае прибегнуть к насилию. В стране почти повсеместно замечается антиправительственное брожение, проявляющееся в восстаниях, бунтах, погромах и военных мятежах» [Белов 2001: 25]

Такие же мятежные настроения были и у тувинцев. Обеспокоенный активизацией заселения страны китайцами, правитель Тувы Комбу-Доржу, а также предчувствуя скорое падение маньчжурской власти, стал предпринимать меры по отделению страны от Китая.

В России царская дипломатия путем пересмотра пограничных договоров и соглашений «пыталась создать общественное мнение, что северная часть Урянхайского края испокон веков была в составе России» [Моллеров, Март-оол 2013: 146]. Русским властям было приказано «... уклоняться от проверки северной границы по Саянскому хребту и перенести границу на наших картах на хребет Танну-Ола» [Колониальная политика... б/г: 172].

\section{Совещания российских властей по «урянхайскому вопросу»}

28 февраля 1911 г. иркутский генералгубернатор, егермейстер Л. М. Князев провел совещание, в котором, кроме чиновников генерал-губернаторства, приняли участие и военные чины, где они обсудили вопросы укрепления юридического положения русской власти в Туве. Участники совещания признали, что Усинское пограничное управление, созданное 1885 г. и состоявшее из начальника, его помощника, переводчика и 6 казаков, совершенно «не отвечает современному положению интересов края» [Собрание архивных документов... 2014: 53], поэтому возложенные на него обязанности должны быть расширены функциями уездной полиции, крестьянского начальника и, возможно, дипломатического агента. Было решено расширить штат и выработать инструкцию для Усинского пограничного начальника. Кроме того, были приняты решения военного характера, в частности о выдаче Усинскому пограничному начальнику 1000 винтовок Бердана и патронов к ним. Ему поручалось сформировать дружину из ополченцев Усинской волости и Урянхайского края и организовать 1-2-недельные курсы обучения. Из Минусинска и Красноярска были направлены в с. Усинск два взвода, а также было разрешено казакам Иркутской и Енисейской губерний переселяться в Урянхайский край с «пособием от казны».

Таким образом, иркутские власти допускали возможный военный конфликт с Китаем. При малейшем осложнении ситуации с Китаем, не говоря уже о войне, русские власти планировали ввести свои войска в Туву. Штаб Иркутского военного округа выработал план занятий Урянхайского края. Согласно этому плану, из Иркутска и Красноярска должны были выдвинуться две сотни. Вместе с тем встал вопрос об увеличении численности Иркутского и Красноярского казачеств, предполагалось провести мобилизацию «казаков второй и третьей очередей». Кроме того, совещание постановило создать в крае переселенческое ведомство.

Русские власти планировали реализовать в Туве уже проверенную на опыте процедуру присоединения Мерва': проведение общего собрания облеченных властью лиц,

${ }^{1}$ Мерв - государство в Средней Азии, пограничное с Афганистаном, которое вошло в состав России в 1885 г. 
где заявляют о принятии русского подданства и «просят прислать русского начальника», затем принесение присяги на верность русскому царю, а русские в свою очередь дают гарантию сохранения религии и оставления ханов «полными властелинами в своих владениях». Для проведения переговоров с амбын-нойоном был направлен Усинский пограничный начальник А. Х. Чакиров, которого снабдили «инструкцией, средствами и конвоем» [Собрание архивных документов... 2014: 54].

8 ноября 1911 г. на особом совещании Совета Министров под председательством В. Н. Коковцева обсудили не только решения, принятые в Иркутске, но и определили дальнейшие меры по укреплению российских политических, культурно-экономических мер в крае.

Посланник царского двора в Пекине, действительный статский советник И. Я. Коростовец в своей депеше поддержал Л. М. Князева в вопросе усиления военных сил в прилегающих к Урянхайскому краю русских районах. Именно в ней Николай II собственноручно начертал: «Нужно отправить в Усинск нашу воинскую часть» [Колониальная политика... б/г: 213].

Противоположной точки зрения придерживался камергер царского двора А. А. Нератов. Он в своем выступлении подчеркнул: «С нашей стороны попытка перейти к более активным действиям в урянхайском вопросе была бы истолкована, как беззастенчивое намерение воспользоваться вспыхнувшею в Китае революцию для сведения своих с ним счетов и для завладения сопредельною частью его земель» [Собрание архивных документов... 2014: 60]. Кроме того, А. А. Нератов предостерегал свои власти о том, что активная колонизация может также вызвать ответные меры со стороны китайцев.

Участники совещания понимали, что в любом случае Китай из-за революционных событий будет ослабленным и «едва ли способным вести в ближайшем времени наступательную политику на своих окраинах» [Собрание архивных документов... 2014: 60]. Поэтому мирная колонизация, т. е. заселение края русскими «засельщиками», по их мнению, в дальнейшем станет основанием «для постепенного склонения нашей политики на путь протектората, а в далеком будущем, может статься, и прямого присоединения Урянхайского края» [Собрание архивных документов... 2014: 61].
Правительство решило поддержать русское население в крае путем организации строительства школ, больниц и оказания ветпомощи. Оно составляло 5000 человек, или «10 \% всего населения края; в нем имеется 80 русских торгово-промышленных предприятий, 120 русских хуторов, 12 деревень и 50 золотопромышленных предприятий и приисков» [Собрание архивных документов... 2014: 60].

Таким образом, в царских кругах отсутствовало единство мнений. В достижении поставленных целей они по-разному видели разрешение данного вопроса. Министерство иностранных дел выступало за дипломатический подход, тогда как Министерство внутренних дел настаивало на военном захвате края. Кроме того, имелись разногласия в действиях и суждениях между центральной и местной властями. В результате Совет Министров определил умеренную политику - постепенного подчинения края мирными средствами.

Распад Цинской империи и объявление независимой Монголии побудили вновь вернуться к вопросу укрепления русского влияния в Туве на высоком уровне. Межведомственная комиссия при Министерстве внутренних дел, которая заседала с 14 по 18 августа 1912 г., обсудила два основных вопроса: 1) порядок заведования пограничными делами в Урянхайском крае и 2) администрирование проживавшего в крае русского населения. Наиболее острая дискуссия развернулась вокруг вопроса о пограничном комиссаре. В должностные обязанности пограничного комиссара входили взаимодействие с иностранными представителями, регулирование пограничных конфликтов, в отдельных случаях они исполняли консульские функции.

Члены комиссии полагали, что сложился наиболее благоприятный момент для укрепления в крае русского влияния, «как в целях политических, так и в целях защиты интересов населяющего край русского населения» [Колониальная политика... б/г: 234], обсуждали вопрос перевода пограничного комиссара Н. Д. Кузьмина ${ }^{1}$ из Амурской

${ }^{1}$ Кузьмин Н. Д. - в 1900-1912 гг. пограничный комиссар Амурской области. Из-за конфликта с первым вице-консулом В. К. Никитиным пограничному комиссару Н. Д. Кузьмину искали новое место работы, но в августе 1912 г. он был переведен в Приморскую область. 
области как наиболее опытного человека, в с. Усинское. Но данное предложение было отвергнуто.

Из-за закрытия законодательной сессии Государственной Думы ввести новую должность не представлялось возможным. Поэтому иркутский генерал-губернатор Л. М. Князев высказал мнение о командировании особо уполномоченного должностного лица, хорошо знавшего край, которое будет обладать «более широкими полномочиями и правами в сравнении с правами пограничных комиссаров» [Колониальная политика... б/г: 234]. Предполагалось, что он должен «действовать в качестве административно-полицейского органа внутреннего управления, а в отношении дел русского населения Урянхайского края - на правах консула» [Собрание архивных документов... 2014: 68]. Кроме прямых прав и обязанностей пограничного комиссара, он был частично наделен и правами дипломатического агента.

В связи с началом процедуры установления протектората России 16 мая 1914 г. Совет Министров обсудил вопрос об «объединении русской власти в крае». По представленным докладам Министерства иностранных дел и Министерства юстиции, он принял документ «Об устройстве управления и судебной части в Урянхайском крае», где было указано на необходимость разработки законопроекта об административном устройстве Урянхайского края, а также предоставления на утверждение Высочайшему Его Императорскому Величеству проекта «Инструкции должностным лицам управления Усинского пограничного округа и Урянхайского края». Последний был утвержден Николаем II 29 июня 1914 г. Условия протектората не позволяли принимать какие-либо законы об административном устройстве Тувы, и поэтому была разработана инструкция, которая «подчинила бы всех должностных лиц местного управления единой власти в лице комиссара по пограничным делам» [Собрание архивных документов ... 2014: 97].

Согласно инструкции, комиссар по делам Урянхайского края как представитель Правительства Российской империи осуществлял «общее руководство и надзор за деятельностью всех лиц, входящих в состав управления данной местности» (п. 2) и наделялся широким кругом полномочий. Он «наблюдал» за недопущением контрабанды (пп. 3-6), исполнял обязанности полиции и судебные решения (п. 11) и т. д. [Собрание архивных документов... 2014: 123-124].

\section{Амбын-нойон Комбу-Доржу}

В декабре 1911 г. в хошунах, возглавляемых амбын-нойоном Комбу-Доржу, началась национально-освободительная борьба против китайцев. Был разгромлен филиал китайской фирмы «Бо Яньбоу» в Эрзине и его окрестностях. Через месяц большая часть этих хошунов была полностью освобождена от китайских торговцев. Это движение достаточно быстро охватило почти всю Туву. После изгнания китайцев из Тувы перед тувинскими нойонами встал вопрос о дальнейшей судьбе страны. «"Вакуум власти" заставил представителей тувинской элиты искать новые формы государственности» [Дацышен, Ондар 2003: 37].

В январе 1912 г. Комбу-Доржу провел совещание с участием тувинских нойонов и влиятельных лам с тем, чтобы определиться по дальнейшей судьбе своего народа. Комбу-Доржу планировал реализовать довольно амбициозный план - образование ханства, в котором он видел себя ханом.

Амбын-нойон осознанно шел на сближение с Россией с целью объединения под своим началом всех тувинских хошунов, прежде всего Салчакского и Тоджинского. И, как правильно заметили В. Г. Дацышен и Г. А. Ондар, тувинская элита боролась «за сохранение и развитие основ национальной государственности» [Дацышен, Ондар 2003: 37].

Участники совещания не смогли выработать единого мнения, интересы нойонов разделились. Амбын-нойон настаивал на отправке делегации во главе со своим сыном в Петербург с просьбой «оказать покровительство и защиту русского царя». Правители хошунов (Салчакского - Балжиням и Тоджинского - Тогмид) выступили за присоединение к Монголии. Тогда Комбу-Доржу пригрозил им, что «совместно с русскими разграбит и выгонит ... из кочевий» [НА ТИГПИ. Р/Ф. Д. 1192. Л. 4]. В действительности русские снабдили Комбу-Доржу небольшим отрядом казаков. Но, несмотря на угрозы, все же Балжиням и Тогмид тайно выехали в Монголию, где они попросили: «Прежде и до сего времени мы имели и имеем тесную связь с Чжалханца-хутухтой и считаемся шабинарами и далее желая находиться под защи- 
той и покровительством Банди-Вачирдара Чжалханца-хутухты и нести по силе возможности все повинности, почтительнейше постановили: единогласно и решительно ... просить принять наши два хошуна ... с их кочевьями под покровительство Богдо-хана» [НА ТИГПИ. Д. 1065. Л. 9].

Позже к ним подключился и правитель Хемчикского хошуна Буян-Бадыргы. Население вышеперечисленных трех хошунов стали данниками Джалханза-хутухты ${ }^{1}$, правителям тувинских хошунов были пожалованы княжеские титулы гуна и вручены печати, что свидетельствовало о независимом положении от амбын-нойона Тувы.

Комбу-Доржу периодически встречался с Усинским пограничным начальником А. Х. Чакировым. На одной из таких встреч «амбын-нойону Комбу-Доржу был пожалован орден Станислава второй степени» [Baсиленко 2014: 128].

15 (24?) февраля 1912 г. чиновники, придерживавшиеся русской ориентации во главе с Иргитом Агван-Шырапом, смогли передать А. Х. Чакирову прошение об установлении протектората над Тувой, которое было подписано мелкими чиновниками Салчакского, Оюннарского и Тоджинского хошунов. Ни сам амбын-нойон, ни правители этих хошунов не поставили свои подписи под этим документом.

Оставшись в меньшинстве, Комбу-Доржу, считая себя не обремененным никакими обязательствами, также обратился к ургинскому хутухте с просьбой принять его хошун в состав Монголии и «вновь подчинить ему тувинские хошуны Салчак и Тоджа» [История Тувы 2001: 314]. После получения согласия со стороны Богдо-хана Комбу-Доржу сразу ходатайствовал о подчинении ему еще двух хошунов - Хубсугульского и Хемчикского, - которые получили самостоятельность в 1878 и 1908 гг. соответственно. Все действия Комбу-Доржу были направлены на реставрацию прежнего административно-территориального устройства Тувы. Но отсутствие опыта государственного строительства, «цепляние» за старую традиционную систему управления помешали ему реализовать свои далеко идущие планы. Фактически получилось, что «тувинцы боролись за сохранение своих

1 Джалханза-хутухта VIII Дамдинбазар монгольский религиозный и политический деятель. Дважды занимал пост первого министра Монголии. прежних социально-экономических устоев и формально политического статуса» [Дацышен, Ондар 2003: 60].

\section{Заведующий пограничными делами Усинского края}

На первых порах в обязанности заведующего входили, в первую очередь, удержание правителей отдельных тувинских хошунов от вхождения в состав Монголии и проведение среди их населения разъяснительной работы о пользе и выгоде «самостоятельного ... существования вне зависимости от Китая или Монголии» [Дацышен, Ондар 2003: 235]. Затем, во вторую очередь, администрирование русских, проживавших в крае.

Первым заведующим пограничными делами был назначен А. П. Церерин, особый чиновник IV класса Иркутского генерал-губернаторства, деятельный, инициативный человек. Во многом благодаря его грамотным действиям в 1914 г. в Туве был установлен российский протекторат. Он приступил к своим прямым обязанностям 22 марта 1913 г. и стал активно знакомиться с внутренними делами Тувы. Особо теплые отношения у него сложились с Комбу-Доржу. А. П. Церерин поддержал его в вопросе образования ханства. Как он потом увлеченно рассказывал В. К. Габаеву, «он, Церерин, поставит одного из пяти урянхайских правителей ханом, а сам будет руководить всеми делами ханства» [Колониальная политика... б/г: 282].

А. П. Церерин выступал против беспорядочного заселения русских крестьян в Туву, в частности остановил движение переселенцев по Чуйскому тракту [Колониальная политика... б/г: 289]. Отвод тувинских земель происходил «по свободному соглашению с урянхами», а любое возмущение местного населения могло привести к повторению событий 1908 г. Тогда правитель Хемчикского хошуна М. Хайдып решил выселить русских торговцев, не имеющих разрешения (свидетельства) на нахождение на территории Тувы. Для регулирования данной проблемы с российской стороны были задействованы Усинский пограничный начальник, иркутский генерал-губернатор, дипломатический корпус в Пекине и Улясутае, агенты, а также военные круги. Заведующий считал, что, пока не откроется Усинская дорога, в случае возникновения конфликта оказать какую-либо защиту 
русским «засельщикам» не представляется возможным. Кроме того, русские сторожилы видели в новых «засельщиках» конкуренцию, и, как свидетельствует чиновник особых поручений С. Р. Минцлов, «купцы, пользующиеся среди сойотского (тувинского) чиновничества большим влиянием, ... позволяют себе враждебно настраивать нойонов против русских» [Колониальная политика... б/г: 301].

Отдельные русские чиновники, в частности красноярский губернатор, судьи, чиновники Казенной палаты, Усинский пограничный начальник, считали территорию Тувы русским уездом, округом и соответственно творили здесь самоуправство, что в скором времени могло привести к нежелательным последствиям для российских властей. Как докладывал А. П. Церерин в своем донесении иркутскому генерал-губернатору: «Хаос и неразбериха во взгляде на урянхайский вопрос ... создались благодаря самостоятельному политиканству относительно Урянхайского края отдельных должностных лиц и учреждений в Красноярске и с. Усинском» [Колониальная политика... б/г: 255].

А. П. Церерин все свои усилия направил на установление дружеских связей с нойонами двух хемчикских хошунов, поскольку их население составляло больше половины коренных жителей всей Тувы, и в них имелось сильное монгольское влияние. Для того чтобы его нейтрализовать, он приказал казакам вылавливать монголов, и, если при них обнаружат агитационные листки, то их следует уничтожать. Он, как его инструктировали, обращали внимание на то, что монголы установили непомерные налоги, и даже были зафиксированы случаи «самовольного захвата и увода скота», а русские власти «не позволят никому другим брать с них (тувинцев) дань и [будут] защищать от притеснений, чинимых со стороны под видом повинностей» [История Тувы 2001: 356], убедил правителей и дзайсанов ${ }^{1}$ двух хемчикских хошунов написать прошение на имя российского императора.

\section{Переселенческий чиновник}

Поскольку русские власти не отказались от идеи активного заселения Тувы новыми засельщиками, кроме заведующего, было предложено назначить и отправить в Туву переселенческого чиновника на правах кре-

\footnotetext{
1 Дзайсан - правитель рода.
}

стьянского начальника. Согласно инструкции, утвержденной 10 мая 1913 г., переселенческий чиновник должен был ведать «русским населением Урянхайского края и всемерно поддерживать его в культурно-хозяйственной работе», т. е. заниматься строительством школ, церквей, молитвенных домов, магазинов, содействовать открытию потребительских обществ, промышленных артелей и товариществ. Он был подотчетен в своей деятельности заведующему пограничными делами Усинского округа.

Переселенческим чиновником был назначен В. К. Габаев, также энергичный и предприимчивый человек, который прибыл в с. Усинское 2 июня 1913 г. Он, в отличие от А. П. Церерина, сразу поселился в Туве и в своих действиях зачастую допускал превышение своих полномочий, тем самым нарушая инструкцию. «Переселенческий чиновник фактически сосредоточил в своих руках всю полноту русской власти в Туве, так как в его руках были деньги, и ему подчинялась местная полиция» [Дацышен, Ондар 2003: 46].

Между А. П. Церериным и В. К. Габаевым не сложились отношения. Они поразному видели решение задач, поставленных центральной властью. А. П. Церерин видел переселенческого чиновника лишь как исполнителя своих отдельных поручений, тогда как В. К. Габаев, невзирая на недовольство местного населения, устраивал на новом месте ежедневно прибывавших переселенцев. Корень конфликта состоял в том, что А. П. Церерин, как уже было сказано выше, проводил осторожную политику, обустраивая новых «засельщиков» только после согласования с тувинскими нойонами, тогда как В. К. Габаев во главу угла ставил интересы русских. Несогласованность действий двух представителей русской власти в крае, своего рода двоевластие, привело к некоторому замешательству среди тувинской политических элиты. А. П. Церерин проигнорировал самый главный проект В. К. Габаева - строительство Белоцарска, даже ни разу не посетив его.

\section{Приезд иркутского генерал-губернатора Л. М. Князева в Усинск и Туву}

Для разрешения сложившейся непростой ситуации 10 августа 1913 г. в Усинск прибыл иркутский генерал-губернатор Л. М. Князев. Его сопровождали прокурор 
Красноярского окружного суда Иванов, дипломатический чиновник Эльтеков, инженер Усинской дороги и адъютант Струве. 12 августа Л. М. Князев провел совещание, где выступил с инициативой выработать положение об управлении Урянхайским краем, а затем провести его в Государственной Думе. Но поскольку ни одно из действовших положений в других областях не подходили для Тувы, а участники совещания не смогли так быстро выработать его самостоятельно, то его предложение так и не было реализовано [Колониальная политика... б/г: 284]. Л. М. Князев понимал, что несогласованность действий двух должностных лиц может загубить все планы Совета Министров, поэтому он выступил за единоначалие в крае и поддержал заведующего пограничными делами А. П. Церерина.

В результате Л. М. Князев только внес изменения в инструкцию заведующего пограничными делами, а инструкцию переселенческого чиновника вовсе отменил. Кроме того, он расформировал Усинское пограничное управление, тем самым передав управление краем Усинскому пограничному комиссару. Таким образом, В. К. Габаева лишили прав крестьянского начальника, полицейские обязанности с него также сняли, и в результате его юридическое нахождение в крае становилось неясным.

За переселенческого чиновника заступился министр внутренних дел Н. Маклаков. Он напомнил Л. М. Князеву о том, что внешняя и внутренняя российская политика направлена на закрепление Урянхайского края за Российской империей, поэтому его мирная колонизация и создание в нем русских интересов «представляется основным мероприятием. А инструкции никоим образом не может быть признаваемы взаимно противоречивыми или несогласованными и приостановлений действия какой-либо из них ни в коем случае не может быть допущено» [Колониальная политика... б/г: 290].

Известно, что Л. М. Князев посещал Туву и встречался с представителями двух хемчикских хошунов. Подробности данной встречи ждут своих исследователей.

5 июля 1915 г. второй раз в Усинск прибыл иркутский генерал-губернатор Л. М. Князев. На этот раз его сопровождали те же дипломатический чиновник Эльтеков и прокурор Красноярского окружного суда Иванов, а также офицер Римский-Корсаков, архитектор Миталь. На совещаниях, кроме докладов В. Ю. Григорьева и В. М. Шкунова, он выслушал вопрос об открытии зимней дороги по Усинскому тракту. Строительство дороги Усинское - Белоцарск началось в 1915 г. и тогда составляло 135 верст $^{1}$.

В Туве Л. М. Князев совершил ознакомительные поездки по русским селениям Малого Енисея - Щербаковке, Федоровке, Бояровке, Шан и Знаменке, где имел возможность беседовать с людьми и призывал всех мирно решать разногласия с местным населением. Дальнейшая поездка до ЧааХоля не состоялась из-за травмы ноги.

\section{Административная реформа до и после объявления российского протектората}

Удалив монгольского даргу, который управлял Бейсе-хошуном, А. П. Церерин временно назначил трех тувинских дзайсанов поочередно заведовать хошуном, а затем созвал совещание с участием 17 представителей родов (отоков), из которых состоит хошун и «духовенства для обсуждения вопроса о желательной для них формы управления хошуном» [Колониальная политика... б/г: 338]. В результате 4-дневного обсуждения правителем хошуна был избран в то время лояльный к русским властям, энергичный, образованный лама Куулар Чымба и четыре его помощника.

Аналогичную процедуру он провел в сомонах Маады и Чооду, которые ранее были данниками монгольского вана Намхайжанцана. Хотя изначально А. П. Церерин хотел присоединить их к управе амбын-нойона, но поскольку чиновники были против, то во главе управления был поставлен чиновник в должности «главный дзайсан» (тэргуун дзайсан) с двумя помощниками. Таким образом, был искусственно образован новый хошун, получивший название Да-ван. Позднее из сомонов Сартул и Шалык, которые также ранее входили в Дзасакту-хановский аймак Монголии, по аналогичному сценарию учрежден новый Нибазы хошун.

Таким образом, благодаря усилиям А. П. Церерина всеми тувинскими хошунами и сомонами стали править тувинские нойоны, но разрозненность между управлениями не удалось преодолеть.

В июне 1914 г. при объявлении о принятии российского протектората в м. Булук

${ }^{1}$ Верста - старинная русская единица измерения расстояния, равная 1066,8 м. 
А. П. Церерин сообщил Комбу-Доржу, что он «принят с подчиненными ему урянхами Оюннарского, Салчжакского и Тоджинского хошунов» [Собрание архивных документов ... 2014: 160]. При этом А. П. Церерин понимал, что вернуть чиновников последних двух хошунов под русское влияние довольно сложно, все его попытки встречи с нойонами Салчакского и Тоджинского хошунов были безрезультатными. Поэтому он намеревался назначить новых нойонов, более лояльных к русским. Но данную процедуру он хотел провести руками Комбу-Доржу. В своем письме А. П. Церерин писал: «...Действия Сальчжакского и Тодчжинского нойонов как незаконные поистине заслуживают всякого порицания ... прошу вас немедленно восстановить свою законную власть над Сальчжакским и Тодчжинским нойонами, и если они окажут вам в этом хотя бы малейшее сопротивление, то вы должны их сместить и избрать вместо их других нойонов» [Колониальная политика... б/г: 344].

При этом с тувинских чиновников было взято обязательство не иметь никаких сношений с иностранцами, «иначе как через посредство лица, представляющего на месте Российского правительство» [НА ТИГПИ. Д. 1065. Л. 16]. В свою очередь тувинские правители, каждый в отдельности, выдвинули следующие требования: ограничить наплыв русского населения, не заселяться самовольно, без разрешения местных властей не возводить постройки на пастбищах и священных местах, сохранить традиционное вероисповедание, самоуправление, уклад жизни и родовые кочевья.

В начале августа 1914 г. умер Балжиням и, соответственно, встал вопрос о новом правителе хошуна. А. П. Церерин предложил Комбу-Доржу воспользоваться удобной ситуацией и назначить своего человека. Но последний не пошел у него на поводу и, следуя традициям, предложил приемного сына Балжиняма - 17-летнего Идам-Суруна $^{1}$. Комбу-Доржу потребовал от наследника явиться к нему и А. П. Церерину для обсуждения насущных вопросов, в том числе о несении повинности.

${ }^{1}$ Идам-Сурун - приемный сын правителя Салчакского хошуна Балжиняма. Его родным отцом был брат Балжиняма - Дамдын, Да-лама хошуна. Он сам также буддийский монах, получил прекрасное домашнее образование.
Bсе усилия, направленные на объединение хошунов под началом амбын-нойона Тувы, были напрасны, поскольку даже правитель сомона Соян Ванчук активно стал продвигать идею выделения сомона в самостоятельное управление и обратился к монголам. В результате он наравне с правителями хошунов получил печать и был награжден титулом «гуна». Затем его сын Талха-Сурун обратился с ходатайством о предоставлении ему отдельного управления.

\section{Комиссар по делам Урянхайского края}

21 июня 1914 г. Государственная Дума утвердила закон об учреждении должности комиссара по делам Урянхайского края. Им был назначен статский советник В. Ю. Григорьев, который прибыл в Туву в начале 1915 г. Ему также ставилась задача мирного слияния Тувы с Российской империей. Заведующим переселенческого управления был назначен В. М. Шкунов.

После установления российского протектората актуальным стал вопрос упорядочения административного устройства края. Решение данного вопроса полностью предоставлялось местным русским властям. Кроме вопросов административного управления отдельными тувинскими хошунами, В. Ю. Григорьев хотел взять под контроль выезды тувинских чиновников всех рангов в Монголию, выдавая собственноручно билеты, а простой народ должен был ездить «с разрешения управляющего хошуном» [НА ТИГПИ. Д. 1065. Л. 4]. Комиссар установил налог, «необходимый для покрытия расходов по хошунному управлению», что, естественно, сразу же вызвало недоумение у местных чиновников, поскольку одним из аргументов, на которое обращал свое внимание А. П. Церерин, было то, что «урянхи ... не будут платить русским никаких податей» [НА ТИГПИ. Д. 1065. Л. 9об.-10].

В отличие от своего предшественника В. Ю. Григорьев встал на путь конфронтации с амбын-нойоном Комбу-Доржу. Последний, в свою очередь разочаровавшись в русских, стал открыто игнорировать комиссара, не реагируя на его просьбы о встрече, и, несмотря на запреты, использовал маньчжурскую печать при переписке с монголами. В. Ю. Григорьев в мае 1915 г., в одну из поездок к амбын-нойону, отстра- 
нил Комбу-Доржу от власти, но «в воздаяние прежних заслуг ...оставил ему почетное звание амбаня» [НА ТИГПИ. Д. 1065. Л. 4об.]. Он обещал посодействовать в получении ежегодной пенсии. Но опять же, видя «непослушание» со стороны амбына, он отказался от своих слов. Затем комиссар, отправив русских казаков, обманным путем отобрал печать амбын-нойона символ власти. Как он потом сообщал, маньчжурскую печать «во избежание дальнейших с нею злоупотреблений, уже отобранную мною от амбаня, я буду бережно хранить у себя, так как хотя она и утратила теперь свое деловое значение, но имеет для каждого урянха дорогое историческое значение, как воспоминание о былой истории народа, как это имеет место у других народов, любящих свою родину и ея прошлое» [ГАРТ. Ф. 115. Оп. 1. Д. 24. Л. 5].

На совещании чиновников Оюннарского хошуна был избран Соднам-Балчыр, сын Комбу-Доржу. Но промонгольски настроенный, он, ссылаясь на болезни, молодость и неопытность, отказался. Прекрасно понимая привязанность тувинцев к своим родовым правителям, а прерывание власти «наследственных амбаней» может привести «к дальнейшим враждебным нам выступлениям» [ГАРТ. Ф. 115. Оп. 1. Д. 24. Л. 143], В. Ю. Григорьев назначил его исполняющим обязанности правителя Оюннарского хошуна, и ему в помощь были назначены два дзахирокчи ${ }^{1}-$ Оюн Ажыкай и Иргит Агван-Шырап. Последнего охарактеризовали как «искреннего русофила, умного, просвещенного и влиятельного человека» [История Тувы 2001: 34].

Соднам-Балчыр также избрал тактику игнорирования В. Ю. Григорьева, продолжая ездить в Монголию и вести переписку с монголами. Эти факты раздражали русского комиссара, и он в августе 1915 г. лишил власти Соднам-Балчыра, объявив его «нечиновным урянхом, которому не представлено и не будет представлено никакой власти» [ГАРТ. Ф. 115. Оп. 1. Д. 24. Л. 4об.]. Комиссар не стал проводить повторные выборы и назначил правителем Оюннарского хошуна дзахирогчи Иргита Агван-Шырапа, а его помощником Оюна Ажыкая.

${ }^{1}$ Дзахирогчи - чиновник при правителе хошуна, ведающий гражданскими делами.

\section{Обострение ситуации после объявления протектората. Приезд А. И. Пильца в Туву}

Монголы, воспользовавшись вступлением России в Первую мировую войну, активизировали действия в попытке распространить свою власть в Туве. Они в своем письме просили встречу с Комбу-Доржу для выяснения вопроса о его ранее подданном прошении, а Буян-Бадыргы, дзайсанам 17 отоков, хамбу-ламе Чамзы и правителям Дзасакту-хановского и Сайн-нойоновского аймаков Монголии приказали восстановить прежнюю власть. Некоторые тувинские чиновники, придерживающие монгольской ориентации, возобновили агитацию против русских и даже открыто выражали угрозы «разгромить всех русских, выгнать их из Урянхая, перебить их и т. д.» [Колониальная политика... б/г: 386]. Только весной 1915 г. заведующему устройством русского населения в крае пришлось разрешать 259 спорных случаев между местным и русским населением [Моллеров, Март-оол 2013: 155].

Когда ситуация стала выходить из-под контроля, в мае 1915 г. комиссар В. Ю. Григорьев вызвал из Усинска местную воинскую команду в количестве 45 человек и 50 казаков из Кобдинского консульского конвоя. Последних, за исключением 7 человек, которых оставили на Хемчике, сосредоточили в Оюннарском хошуне для поимки гуна Ванчика, а Усинскую команду разместили в Салчакском хошуне, чтобы следить за развитием событий при выборе правителя хошуна.

Иркутский генерал-губернатор А. И. Пильц, назначенный «для восстановления престижа власти, поколебленной мягкостью Князева» [Адамов 2007: 41], посчитал недостаточным количество военных сил в крае и приказал в срочном порядке произвести мобилизацию порядка 600 человек с запаса и ополчения [Адамов 2007: 40]. Таким образом, в Туве вводилось военное положение.

По оценке царских дипломатов в Монголии, русские власти в Туве преувеличивали роль монголов в тувинско-русском противостоянии в вышеуказанных двух хошунах.

Видя обострение ситуации, А. И. Пильц решил сам вмешаться и в августе 1916 г. выехал в Туву, решив побывать «в наиболее важных туземных центрах» [Адамов 2007: 40]. Он сообщал: «В случае нужды буду применять самые решительные меры, 
даже не предусмотренные законами, ибо сойоты, видя нашу слабость и одновременно настойчивость монгольского правительства ... совершенно перестают признавать» русскую власть [Адамов 2007: 40-41]. Иркутский генерал-губернатор, убедившись в сильном тяготении южных тувинцев к монголам, «объявил урянхам ... бесповоротную принадлежность края России (подчеркнуто Е. Адамовым. - A. C.), обязанность подчиняться местным властям..., предупредив, что ослушников подвергну строгим карам и высылке в отдаленные местности Сибири» [Адамов 2007: 41]. При этом А. И. Пильц прекрасно понимал, что каких-либо юридических оснований для реализации своих угроз у него нет, поскольку условия протектората не позволяли полностью ввести российскую юрисдикцию.

Летом 1916 г. в результате устроенной засады сторонниками Соднам-Балчыра назначенец В. Ю. Григорьева Агван-Шырап был ранен и вскоре умер. Поэтому вновь встал вопрос о правителе хошуна.

Перед самым приездом А. И. Пильца 30 июля 1916 г. состоялся съезд Оюннарского хошуна, где вновь правителем хошуна был избран Соднам-Балчыр. Последний попытался вернуть утраченную власть и явился на аудиенцию к генерал-губернатору, выразив «раскаяние в противодействии русским и обещал в будущем быть верным слугой государя императора» [Адамов 2007: 42]. Иркутский генерал-губернатор вновь назначил Соднам-Балчыра правителем хошуна с условием, что он будет пресекать «распространение монгольской агитации» [Адамов 2007: 41].

Пожалуй, главным результатом поездки генерал-губернатора стало то, что южная граница стала считаться не по Танну-Ола, как это долгое время разрабатывали в русских дипломатических кругах, а по «течению реки Теси, что необходимо было по этнографическим, военным и экономическим соображениям» [Адамов 2007: 42]. Это необходимо, считал он, что «долина между хребтом и рекой составляет необходимые зимние кочевья наших урянхов» [Адамов 2007: 42].

\section{Выводы}

Волна революции, вспыхнувшей в Китае, привела к глубоким преобразованиям и в Туве. Русские и монголы, каждый со своей стороны, активизировали свои действия в борьбе за владение Тувой. Тувинские нойоны пытались сохранить свою автономность, но «уровни развития экономических, политических институтов ... были явно недостаточны для формирования полностью независимого и достаточного сильного государства» [Дацышен, Ондар 2003: 234].

Российский протекторат, установленный в 1914 г. и не закрепленный международными договорами, привел к обострению ситуации не только на внешнем (с китайцами и монголами) уровне, но и внутреннем - среди тувинской элиты и русских представителей. Но благодаря грамотным действиям последних удалось закрепить условия протектората.

В результате грамотных действий русских властей удалось отстранить от власти монголов и поставить своих людей.

\section{ИСТОЧНИКИ / SOURCES}

ГАРТ - Государственный архив Республики Тыва. [Gosudarstbennyy arkhiv Respubliki Tyva [State Archive of the Tyva Republic].]

Колониальная политика... - Колониальная политика русского царизма в Туве. Сб. документов. [Б. и., б. г.]. 472 с. [Kolonial'naya politika russkogo tsarizma $v$ Tuve [Colonial policy of the Russian Tsarist regime in Tuva]. Collected documents. 472 p. (In Rus.)]

НА ТИГПИ - Научный архив Тувинского института гуманитарно-прикладных исследований. [Nauchnyy arkhiv Tuvinskogo instituta gumanitarno-prikladnykh issledovaniy [Scientific Archive of the Tuvan Institute for Humanities and Applied Socio-Economic Research].]

Собрание архивных документов ... 2014 - Собрание архивных документов о протекторате России над Урянхайским краем (Тувой) (К 100-летию исторического события). Кызыл: [б. и.], 2014. 479 с. [Sobranie arkhivnykh dokumentov o protektorate Rossii nad Uryankhayskim kraem (Tuvoy) (K 100-letiyu istoricheskogo sobytiya) [Collected archival documents about Russia's protectorate over Tannu Uriankhai (Tuva) (celebrating the $100^{\text {th }}$ anniversary of the historical event)]. Kyzyl, 2014. 479 p. (In Rus.)]

\section{ЛИТЕРАТУРА / REFERENCES}

Адамов 2007 - Адамов $E$. A. Урянхайский вопрос при царском и Временном правительствах. Кызыл: КЦО Аныяк, 2007. 71 с. [Adamov E. A. Uryankhayskiy vopros pri tsarskom $i$ Vremennom pravitel'stvakh [The 'Uriankhai issue' as viewed by the Tsarist and Russian Pro- 
visional Governments]. Kyzyl: Anyyak, 2008. 71 p. (In Rus.)]

Белов 2001 - Белов Е. А. Краткая история Синьхайской революции. 1911-1913. Уч. пособие. М.: Вост. лит., 2001. 160 с. [Belov Е. А. Kratkaya istoriya Sin'khayskoy revolyutsii. 1911-1913 [A brief history of the Xinhai Revolution: 1911-1913]. A study book. Moscow: Vost. Lit., 2001. 160 p. (In Rus.)]

Василенко 2014 - Василенко В. А. На пути к протекторату (Отношения правительства имперской России с Китаем и Монголией по вопросам установления политического влияния в Туве во второй половине XIX в. - 1914 г.). Иркутск: Изд-во ИГУ, 2014. 223 c. [Vasilenko V. A. Na puti k protektoratu. (Otnosheniya pravitel'stva imperskoy Rossii s Kitaem i Mongoliey po voprosam ustanovleniya politicheskogo vliyaniya $v$ Tuve vo vtoroy polovine XIX v. - 1914 g.) [On the way towards a protectorate (Imperial Russia's relations with China and Mongolia concerning its political protectorate over Tuva in the 1950s up to 1914)]. Irkutsk: Irkutsk State Univ., 2014. 223 p. (In Rus.)]
Дацышен, Ондар 2003 - Даџышен В. Г., Ондар $\Gamma$. А. Саянский узел: Усинско-Урянхайский край и российско-тувинские отношения в 1911-1921 гг. Кызыл: республиканская типография, 2003. 284 с. [Datsyshen V. G., Ondar G. A. Sayanskiy uzel: UsinskoUryankhayskiy kray $i$ rossiysko-tuvinskie otnosheniya v 1911-1921 gg. [The Sayan imbroglio: Usinsk-Uriankhai Region and Russia-Tuva relations in 1911-1921]. Kyzyl: Republic Publ., 2003. 284 p. (In Rus.)]

История Тувы 2001 - История Тувы. Т. 1. Новосибирск: Наука, 2001. 364 с. [Istoriya Tuvy [A history of Tuva]. Vol. 1. Novosibirsk: Nauka, 2001. 364 p. (In Rus.)]

Моллеров, Март-оол 2013 - Моллеров Н. М., Март-оол В.Д. С. Урянхайский вопрос в политической истории России: возникновение и долговременная актуальность. Кызыл, 2013. 244 c. [Mollerov N. M., Mart-ool V.D. S. Uryankhayskiy vopros $v$ politicheskoy istorii Rossii: vozniknovenie $i$ dolgovremennaya aktual'nost' [The 'Uriankhai issue' in Russia's political history: emergence and long-lived relevance]. Kyzyl, 2013. 244 p. (In Rus.)]

UDC 9 (с 18 тув)

\section{The Increasing Political Influence of Russia and Administrative Reform in Tuva}

Ayana A. Samdan ${ }^{1}$

${ }^{1}$ Ph.D. in History (Cand. of Historical Sc.), Leading Research Associate, Tuvan Institute for Humanities and Applied Socio-Economic Research (4, Khochetov Str., Kyzyl, 667000, Russian Federation). ORCID: 0000-0002-7785-7497.E-mail: camayana@mail.ru

\footnotetext{
Abstract

Introduction: The article studies a number of archival materials — some of the latter being newly introduced into scientific discourse - and examines the incorporation of Tuvans into Russia's political space through the establishment of its protectorate over Tannu Uriankhai. The Tsarist Government would elaborate different plans to spread its influence, including somewhat military annexation of the territory. The problems were negotiated at multiple levels of the Russian power structures. A most debating point proved the task of administering both the native and Russian populations. The consultations resulted in shaping a moderate policy aimed to strengthen their positions through inflows of ethnic Russian peasants into Tuva.

Goals: The paper aims to investigate some issues of administrative and territorial management in Tuva after the establishment of Russia's protectorate in 1914.

Methods: The applied empirical methods included comparisons, descriptions, interpretations, and system analysis; the theoretical ones comprised historicism patterns and those of formal and dialectical logic.
} 
Results: The actual political situation required that certain corrections be introduced into the regional management system, namely: Russian administrative bodies were to be organized, their competences to be delineated, protocols for liaison between the Commissariat, Migration Department, and their relations to local authorities, Russian and Tuvan populations to be clarified. Representatives of the Russian Government employed experienced, initiative officials (A. Tsererin, V. Gabaev, V. Grigoriev) whose efficient and active efforts largely contributed to the establishment of the protectorate and facilitated the subsequent implementation of administrative and territorial reforms in the region. A number of important tasks (e.g., construction of the Usinsky Tract, conflicts between natives and newly arrived groups) required the involvement of the Governor-General of Irkutsk.

Conclusions: The Xinhai Revolution gave Russia an opportunity to strengthen its positions in Tuva. The Russian officials chose the path of indirect governance through establishing close contacts with khoshun (Tuv. kozhuun 'district') rulers or appointing loyal individuals. The approach facilitated the formation of new political elites in Tuva. As a result, the Mongols were removed from power, and all Tuvan khoshuns and sumons (Tuv. sumon 'township') were governed by natives. So, Lama $\mathrm{K}$. Chymba was elected as head of one of the multiple khoshuns, and four sumons were transformed into two new khoshuns.

The then Tuvan political elites failed to come to a consensus about national self-determination, which partly stemmed from somewhat indifferent attitudes of theirs towards Tuva's future and the still lingering inclinations to former administrative procedures.

Keywords: Tannu Uriankhai, Russian authorities, Kombu Dorzhu, protectorate, consultations, Governor-General of Irkutsk, administrative reform, Xinhai Revolution 